\title{
The Impact of Online Learning Policies on Students' Learning Motivation in the Era of the Covid-19 Pandemic
}

\section{Dampak Kebijakan Pembelajaran Daring Terhadap Motivasi Belajar Siswa Pada Era Pandemi Covid-19}

\author{
Umi Hanifah", Nida Anisah Firdaus \\ Fakultas Tarbiyah dan Keguruan, Universitas Islam Negeri Sunan Ampel Surabaya, Indonesia
}

Covid-19 is an epidemic originating from Wuhan, China that spread rapidly throughout the world. Covid-19 spread in Indonesia in early March 2020. The spread of this virus caused losses to many countries in various fields ranging from the economy, tourism, to education. In the field of education, the impact of Covid-19 was forced to make the government change the learning system drastically; all learning activities are carried out online starting from elementary school to college. The purpose of this study is was to describe the impact of online learning policies on the learning motivation of high school students and their equivalents during the Covid-19 pandemic. This study is a qualitative descriptive study. Data collection uses a research questionnaire through a Google form that is distributed to high school students and their equivalents in East Java. Based on the results of the study, respondents revealed more negative impacts than positive impacts. From the results of this research the government is expected to be more mature in determining policies even though it is an emergency policy.

ISSN 25482254 (online) ISSN 20893833 (print)

Edited by: Rifki Afandi

Reviewedby:

Deni Adi Putra

${ }^{*}$ Correspondence:

Umi Hanifah

umihanifah78@yahoo.com

Received: 30 Maret 2021 Accepted: 16 November 2021 Published: 21 November 2021

Citation:

Hanifah U, Firdaus NA (2021) The Impact of Online Learning Policies on Students' Learning Motivation in the Era of the Covid-19 Pandemic. Pedagogia: Jurnal Pendidikan. 11:1. doi: 10.21070/pedagogia.v11i1.1246
Keywords: Covid-19, Impact, Learning Motivation, Online Learning, Policy

Covid-19 merupakan wabah penyakit yang berawal dari Wuhan, China yang menyebar dengan cepat ke seluruh penjuru dunia. Covid-19 menyebar di Indonesia pada awal Maret 2020. Penyebaran virus ini menyebabkan kerugian untuk banyak negara di berbagai bidang mulai dari ekonomi, pariwisata, sampai pendidikan. Dalam bidang pendidikan, dampak Covid-19 memaksa pemerintah mengubah sistem pembelajaran secara drastis; seluruh kegiatan pembelajaran dilakukan secara daring mulai dari pendidikan anak usia dini, sekolah dasar, sampai perguruan tinggi. Tujuan kajian ini adalah untuk mendekripsikan dampak kebijakan pembelajaran daring terhadap motivasi belajar siswa SMA/MA sederajat di Jawa Timur pada saat pandemi Covid-19. Kajian ini menggunakan metode deskriptif kualitatif. Pengumpulan data menggunakan kuesioner melalui google form yang disebar ke para siswa SMA/MA sederajat di Jawa Timur. Berdasarkan hasil analisis data, disimpulkan bahwa dampak negatif lebih banyak diungkapkan responden dari pada dampak positif, seperti kurang 
adanya inovasi pembelajaran dari guru sehingga siswa sulit untuk memahami pembelajaran, sinyal dan kuota internet yang kurang memadai, menurunnya intensitas belajar siswa, dan lain sebagainya yang menyangkut motivasi belajar siswa. Dari hasil riset ini diharapkan pemerintah lebih matang lagi dalam menentukan kebijakan walaupun itu kebijakan darurat.

Kata Kunci: Covid-19, Dampak, Motivasi Belajar, Pembelajaran Daring, Kebijakan. 


\section{PENDAHULUAN}

Wabah coronavirus sedang marak-maraknya terjadi di negara Indonesia, bahkan di seluruh negara di dunia saat ini. Severe acute respiratory syndrome coronavirus 2 (SARS-CoV-2) yang lebih dikenal dengan nama virus Corona adalah jenis baru dari coronavirus yang menular ke manusia. Walaupun lebih bayak menyerang lansia, virus ini sebenarnya bisa menyerang siapa saja, mulai dari bayi, anak-anak, hingga orang dewasa. Infeksi virus Corona disebut COVID-19 (Corona Virus Disease 2019) dan pertama kali ditemukan di kota Wuhan, China pada akhir Desember 2019. Virus corona adalah kumpulan virus yang bisa menginfeksi sistem pernapasan. Pada banyak kasus, virus ini hanya menyebabkan infeksi pernapasan ringan, seperti flu. Namun, virus ini juga bisa menyebabkan infeksi pernapasan berat, seperti infeksi paru-paru (pneumonia). Masa inkubasi rata-rata 5-6 hari dengan masa inkubasi terpanjang 14 hari. Virus ini menular dengan sangat cepat dan telah menyebar ke hampir semua negara, termasuk Indonesia, hanya dalam waktu beberapa bulan. Pada tanggal 30 Januari 2020, WHO (World Health Organization) telah menetapkan sebagai kedaruratan kesehatan masyarakat yang meresahkan dunia. Pada tanggal 2 Maret 2020, Indonesia melaporkan kasus konfirmasi COVID19 sebanyak 2 kasus. Sampai pada tanggal 16 Maret 2020 ada 10 orang dinyatakan positif COVID-19 yang terjadi di Indonesia. Samudera (2020).

Di tengah pandemi Covid-19 yang menyebabkan kondisi krisis yang melanda Indonesia bahkan dunia saat ini, segala upaya dilakukan untuk saling bahu-membahu menyejahterakan seluruh elemen masyarakat pada bidang apapun. Pasalnya, dengan adanya Covid-19 di Indonesia saat ini berdampak bagi seluruh masyarakat. Dampak virus COVID-19 terjadi diberbagai bidang seperti sosial, ekonomi Engkus et al., (2020) pariwisata Sugihamretha (2020), dan pendidikan Samudera (2020). Surat Edaran (SE) yang dikeluarkan pemerintah pada 18 Maret 2020 berisi tentang segala kegiatan didalam dan diluar ruangan di semua sektor sementara waktu ditunda demi mengurangi rantai penyebaran Covid-19 terutama pada bidang pendidikan. Pada tanggal 24 maret 2020 Menteri Pendidikan dan Kebudayaan Republik Indonesia mengeluarkan Surat Edaran Nomor 4 Tahun 2020 Tentang Pelaksanaan Kebijakan Pendidikan Dalam Masa Darurat Penyebaran COVID. Dalam Surat Edaran tersebut dijelaskan bahwa proses belajar dilaksanakan di rumah melalui pembelajaran daring atau jarak jauh dilaksanakan untuk memberikan pengalaman belajar yang bermakna bagi siswa. Belajar di rumah dapat difokuskan pada pendidikan kecakapan hidup antara lain mengenai pandemi Covid-19.

Pembelajaran yang dilaksanakan pada sekolah menengah atas (SMA/MA sederajat) juga menggunakan pembelajaran daring atau jarak jauh dengan melalui bimbingan orang tua. Pembelajaran daring menurut Isman (2017) merupakan pemanfaatan jaringan internet dalam proses pembelajaran. Dengan pembelajaran daring siswa memiliki keleluasaan waktu belajar, dapat belajar kapanpun dan dimanapun. Siswa dapat berinteraksi dengan guru menggunakan beberapa aplikasi seperti classroom, video converence, telepon atau live chat, zoom maupun melalui whatsapp group. Pembelajaran ini merupakan inovasi pendidikan untuk menjawab tantangan akan ketersediaan sumber belajar yang variatif. Tolak ukur keberhasilan dari model maupun media pembelajaran tergantung dari karakteristik peserta didik masing-masing, terutama dalam motivasi belajar yang mereka miliki. Sebagai mana yang diungkapkan oleh Nakayama bahwa dari seluruh literatur e-learning mengindikasikan bahwa tidak semua peserta didik akan sukses dalam pembelajaran online. Hal tersebut dikarenakan faktor lingkungan belajar dan karakteristik peserta didik. Nakayama et al., (2007)

Dengan didukung aplikasi meeting atau online lainnya, melakukan pembelajaran dari rumah tentu tidaklah menyulitkan lagi. Kegiatan belajar mengajar tidak lagi dilakukan di sekolah, melainkan dari rumah masing-masing dengan metode kelas daring atau e-learning dengan menggunakan berbagai aplikasi yang tersedia menggunakan internet. Namun, hasil belajar merupakan cerminan kemampuan penguasaan peserta didik atas mata pelajaran yang diajarkan. Hasil belajar yang tinggi merupakan lambang keberhasilan seorang peserta didik dalam studinya. Dalam pembelajaran, faktor motivasi memiliki pengaruh yang sangat penting, karena merupakan salah satu faktor yang sangat menentukan hasil belajar peserta didik. Dalam hal ini, motivasilah yang menjadikan perilaku peserta didik untuk bekerja atau belajar dengan penuh inisiatif, kreatif dan terarah Muhammad (2017). Dengan begitu, dalam pembelajaran daring (online) haruslah disambut dan diiringi oleh motivasi belajar peserta didik yang tinggi agar pembelajaran dapat berjalan secara efektif dan memperoleh hasil yang baik.

Kajian para akademisi dan ahli pendidikan tentang dampak pembelajaran daring terhadap motivasi belajar siswa pada masa Pandemi Covid-19 ini, telah banyak dilakukan, di antaranya penelitian berjudul "Motivasi Belajar Siswa SMA pada Pembelajaran Daring di Masa Pandemi Covid-19" Cahyani et al., (2020), juga penelitian yang berjudul "Pengaruh Pembelajaran Daring terhadap Minat Belajar Siswa pada Masa COVID 19" Yunitasari \& Hanifah (2020). Kedua penelitian tersebut fokus pada pencarian data tentang dampak negatif pandemi Covid-19 terhadap tingkat motivasi belajar siswa dalam pembelajaran daring dan upaya mencari sebab-sebab yang mempengaruhi motivasi belajar siswa tersebut. Hasil dari kedua penelitian tersebut menunjukkan bahwa motivasi belajar siswa yang mengikuti pembelajaran daring atau online di tengah situasi pandemi Covid 19 menurun. Hal tersebut disebabkan oleh beberapa hal, di antaranya karena kondisi lingkungan belajar, kendala piranti belajar daring, tidak adanya pendampingan guru dan kurangnya pengawasan orangtua serta adanya rasa bosan karena kurangnya inovasi guru dalam mendesain pembelajaran daring.

Dalam kajian ini, penulis mengkaji tentang dampak positif dan negatif kebijakan pembelajaran daring oleh pemerintah terhadap motivasi belajar siswa SMA/MA sederajat di Jawa Timur dengan menjadikan hasil dari penelitian sebagai usulan pertimbangan dan rekomendasi kepada pemerintah terkait jangka waktu pemberlakuan pembelajaran daring di SMA/MA, yakni apakah kebijakan pembelajaran daring ini akan diperpanjang, dihentikan atau divariasikan dengan menambahkan pembelajaran luring dengan bentuk Hybrid learning/blended learning berdasarkan wilayah sekolah. Pembelajaran hybrid learning atau blended learning adalah pembelajaran yang menggabungkan semua bentuk 
pembelajaran misalnya online, live, maupun tatap muka (konvensional) Purmadi \& Hadi (2018) atau perpaduan metode belajar tatap muka (di dalam kelas) dengan materi yang diberikan secara online. Bibi \& Jati (2015)

\section{METODE}

Metode yang digunakan dalam kajian ini menggunakan pendekatan penulisan kualitatif yang ditujukan untuk memahami fenomena-fenomena sosial dari sudut pandang atau perspektif partisipan. Penulisan kualitatif adalah penulisan yang berlandaskan filsafat post positivisme yang digunakan untuk meneliti kondisi objek yang alamiah dimana penulis sebagai instrumen kunci dan hasil penulisannya lebih menekankan makna daripada generalisasi. Partisipan adalah orang-orang yang diajak untuk berwawancara, diobservasi, diminta memberikan data, pendapat, pemikiran dan persepsinya Sukmadinata \& Syaodih (2013). Jenis pendekatan penulisan yang digunakan penulis bersifat deskriptif, yakni penulis menggambarkan pemecahan masalah yang diselidiki, dengan menggambarkan atau melukiskan keadaan objek yang diteliti pada saat sekarang, berdasarkan fakta-fakta yang tampak atau sebagaimana adanya. Nawawi (1996)

Di dalam kajian ini, data yang dikumpulkan berupa kalimat dan penjabaran jawaban dari subjek yang dilakukan dengan pengisian angket atau kuesioner. Angket atau kuesioner (questionnaire) merupakan suatu teknik atau cara pengumpulan data secara tidak langsung (penulis tidak langsung bertanya-jawab dengan responden). Instrumen atau alat pengumpulan datanya juga disebut angket, berisi sejumlah pertanyaan yang harus dijawab atau direspon oleh responden Sukmadinata \& Syaodih (2013). Adapun jenis angket yang digunakan dalam proses penulisan kajian ini adalah jenis angket tertutup yang berisi 20 pertanyaan yang sudah tersedia opsi jawaban-jawabannya dan responden tinggal memilih. Penulis juga menyiapkan 1 pertanyaan terbuka untuk responden yakni untuk mengetahui perspektif responden lebih mendalam tentang masalah yang akan diteliti. Pembuatan angket ini penulis menggunakan google form karena lebih mudah diakses dan dijangkau.

Pengambilan subjek dengan melakukan share link atau kode QR ke seluruh sosial media penulis dengan tetap mencantumkan broadcast yang berisi judul penulisan dan pembatasan responden. Subjek terdiri dari minimal 3 peserta didik SMA/MA sederajat dari tiap-tiap kabupaten/kota di Jawa Timur. Instrumen penulisan terdiri dari penulis sebagai instrumen utama dengan instrumen bantu angket atau kuesioner. Data dalam penulisan ini berupa hasil kuesioner dari responden yang merupakan jawaban dari subjek yang dari situ penulis dapat menjabarkan deskripsi dari dampak kebijakan pembelajaran daring terhadap motivasi belajar siswa SMA/MA sederajat di Jawa Timur.

\section{HASIL DAN PEMBAHASAN}

\section{Kebjakan Pembelajaran Daring di Indonesia}

Untuk mencegah meluasnya penularan Covid-19 dan mengurangi dampak negatif Covid-19, Pemerintah Republik Indonesia melalui Kementerian Pendidikan dan Kebudayaan dan Kementerian Agama telah menerapkan sistem pembelajaran daring di sekolah dan perguruan tinggi melalui media online. Sebenarnya, pelaksanaan pembelajaran daring di masa Pandemi Covid-19 merupakan rekomendasi dan seruan dari Organisasi Pendidikan, Ilmu Pengetahuan dan Kebudayaan (UNESCO) dan Organisasi Kesehatan Dunia (WHO) karena adanya penutupan lembaga pendidikan sementara selama masa pandemi. UNESCO dan WHO meminta kepada semua negara untuk melaksanakan pembelajaran daring dengan berbagai strategi penyampaian yang dapat diakses dengan mudah oleh siswa. Al-Taweel et al., (2021).

Berdasarkan data dari UNESCO tanggal 19 Maret 2020, terdapat 112 negara telah menerapkan kebijakan belajar dari rumah (BDR), antara lain Thailand, Malaysia, Austria, Jerman, Meksiko, Yaman, dan Afrika Selatan. Dari 112 negara yang menerapkan BDR tersebut, 101 negara menerapkan kebijakan belajar dari rumah secara nasional. Sedangkan 11 negara sisanya, termasuk negara Indonesia, menerapkan BDR di daerah-daerah tertentu. kompas. id (2020) Merespon rekomendasi WHO tersebut, Pemerintah Republik Indonesia melalui Kementerian Pendidikan dan Kebudayaan (Kemendikbud) telah menerbitkan beberapa surat edaran terkait pencegahan dan penanganan pandemi Covid-19. Pertama, Kemendikbud mengeluarkan Surat Edaran Nomor 2 Tahun 2020 tentang Pencegahan dan Penanganan kasus Covid-19 di Lingkungan Kemendikbud. Kedua, Surat Edaran Nomor 3 Tahun 2020 tentang Pencegahan penyebaran Covid-19 pada Satuan Pendidikan. Ketiga, Surat Edaran Nomor 4 Tahun 2020 tentang Pelaksanaan Kebijakan Pendidikan dalam Masa Darurat Penyebaran Coronavirus Disease (Covid-19) Arifa (2020). Dalam Surat Edaran tersebut dijelaskan bahwa proses belajar dilaksanakan di rumah melalui pembelajaran daring atau pembelajaran jarak jauh. Magdalena et al., (2020); Gunawan (2020).

Pada beberapa daerah, proses pembelajaran daring telah berlangsung sejak 16 Maret 2020 dan kemudian diperpanjang dengan mempertimbangkan situasi di masing-masing daerah. Dari sisi sumber daya manusia, pendidik maupun peserta didik ada yang memang sudah siap. Tetapi banyak pula yang terpaksa harus siap menghadapi pembelajaran yang biasanya dilaksanakan secara tatap muka berubah menjadi sistem belajar jarak jauh secara daring. Bagi sekolah yang telah terbiasa menggunakan perangkat teknologi dalam kegiatan belajar mengajar tentu tidak banyak menghadapi kendala, Akan tetapi tidak demikian bagi sekolah yang belum pernah melaksanakan pembelajaran daring sebelumnya, terutama di daerah dengan fasilitas yang terbatas baik sisi media belajar online maupun jaringan Arifa (2020). Hal tersebut terjadi karena dalam pembelajaran online dengan konektivitas internet yang lemah, akses terbatas ke teknologi, dan sumber daya manusia yang rendah, akan menciptakan hambatan terhadap interaksi siswa secara aktif dalam proses pembelajaran, sehingga pembelajaran tidak bisa berjalan secara optimal. Abou-Khalil et al., (2021).

\section{Motivasi Belajar Siswa dalam Belajar Daring}

Diagram 1. Hasil Skala Penelitian Motivasi Belajar Siswa Selama Pembelajaran Daring Siswa SMA - Sederajat di Jawa 
Timur.

\section{[Figure 1 about here.]}

Berdasarkan hasil penelitian yang ditunjukkan pada diagram 1, diagram batang berwarna biru menunjukkan hasil yang positif, dan diagram batang berwarna merah menunjukkan hasil yang negatif. Dapat kita lihat bahwa dari keenam indikator yang telah peneliti lakukan untuk memperoleh tingkatan motivasi belajar siswa SMA-sederajat di Jawa Timur dalam pembelajaran daring selama pandemi Covid-19, yang diteliti dengan menggunakan kuesioner melalui google form meliputi: kedisiplinan, antusias, kejujuran, daya tangkap, peningkatan pengetahuan, dan kondisi piskis, menunjukkan diagram batang merah yang memperoleh nilai lebih signifikan dari pada diagram batang biru.

Dalam indikator kedisiplinan yang meliputi ketepatan waktu dan disiplin dalam mengerjakan tugas, hasil yang peneliti peroleh adalah 47,5\% siswa dapat mengerjakan tugasnya dengan baik dan tepat waktu. Sedangkan 52,5\% siswa lainnya menunjukkan bahwa mereka memiliki kendala yang membikin mereka menjadi tidak disiplin dalam mengerjakan tugas sekolah. Dalam indikator antusias yang meliputi perhatian siswa dalam melakukan pembelajaran serta menambah jam belajar mereka untuk mengulang materi, diperoleh 39,6\% siswa dengan tingkat keantusiasan belajar yang tinggi, dan 60,4\% lainnya berada di tingkat antusias belajar yang sedang sampai rendah.

Dalam indikator kejujuran memiliki diagram batang merah yang paling tinggi yakni sebesar $84,4 \%$ siswa yang tingkat kejujurannya rendah saat melakukan pembelajaran daring, sedangkan $16,6 \%$ lainnya melakukan pembelajaran daring dengan penuh kejujuran, tidak menyontek, dan tidak memperoleh bantuan dari orang tua maupun guru les. Dalam indikator daya tangkap yang meliputi tingkat kepahaman siswa dalam memahami materi yang disampaikan oleh guru, sebesar 29,3\% siswa dapat dengan mudah memahami apa yang disampaikan oleh guru, sedangkan $70,7 \%$ lainnya memiliki kendala tidak dapat mudah memahami materi yang disampaikan oleh guru. Dalam indikator peningkatan pengetahuan disini diagram batang merah menunjukkan hasil yang tinggi juga. Sebesar $81,8 \%$ siswa selama pembelajaran daring, mereka merasa tidak memperoleh peningkatan pengetahuan mereka. Sedangkan 22,2\% lainnya menunjukkan angka yang positif. Terakhir, dalam indikator kondisi piskis, sebanyak 37,3\% siswa menunjukkan kondisi piskis yang positif dalam belajar. Sedangkan sebanyak $62,7 \%$ lainnya menunjukkan kondisi psikis yang buruk bagi mereka, seperti stress dan bosan dalam belajar. Sanjaya (2010) mengatakan bahwa proses pembelajaran motivasi merupakan salah satu aspek dinamis yang sangat penting. Sering terjadi siswa yang kurang berperestasi bukan disebabkan oleh kemampuannya yang kurang, akan tetapi dikarenakan tidak adanya motivasi untuk belajar sehingga ia tidak berusaha untuk mengerahkan segala kemampuannya.

Motivasi diartikan sebagai kekuatan, dorongan, kebutuhan, semangat, tekanan atau mekanisme psikologis yang mendorong seseorang atau sekelompok orang untuk mencapai prestasi tertentu sesuai dengan apa yang dikehendakinya. Lesmana et al., (2020) Motivasi adalah suatu dorongan kehendak yang menyebabkan seseorang melakukan suatu perbuatan untuk mencapai tujuan tertentu. Motivasi juga berarti suatu kondisi atau status internal yang mengarahkan perilaku seseorang untuk aktif bertindak dalam rangka mencapai suatu tujuan. Inah \& Khairunnisa (2019) Motivasi juga merupakan sejumlah proses, yang bersifat internal atau eksternal bagi seorang individu, yang menyebabkan timbulnya sikap antusiasme dan persistensi, dalam hal melaksanakan kegiatan-kegiatan tertentu.

Motivasi belajar merupakan suatu keadaan yang terdapat pada diri seseorang individu di mana ada suatu dorongan untuk melakukan sesuatu guna mencapai tujuan. Menurut Mc Donald dalam Kompri (2015) motivasi adalah suatu perubahan energi dari dalam pribadi seseorang yang ditandai dengan timbulnya afektif (perasaan) dan reaksi untuk mencapai tujuan. Dengan demikian munculnya motivasi ditandai dengan adanya perubahan energi dalam diri seseorang yang dapat disadari atau tidak. Menurut Woodwort (1995) dalam Sanjaya (2010) bahwa suatu motivasi adalah suatu set yang dapat membuat individu melakukan kegiatankegiatan tertentu untuk mencapai tujuan. Dengan demikian motivasi merupakan dorongan yang dapat menimbulkan perilaku tertentu yang terarah terhadap pencapaian suatu tujuan tertentu. Perilaku atau tindakan yang ditunjukkan seseorang dalam upaya mencapai tujuan tertentu sangat tergantung dari motivasi yang dimilikinya. Sebagaimana yang diungkapkan oleh Arden (1995) dalam Sanjaya (2010) bahwa kuat lemahnya atau semangat tidaknya usaha yang dilakukan seseorang untuk mencapai tujuan akan ditentukan oleh kuat lemahnya motivasi yang dimiliki orang tersebut.

Motivasi adalah serangkaian usaha untuk menyediakan kondisi-kondisi tertentu, sehingga seseorang mau dan ingin melakukan sesuatu dan bila tidak suka maka akan berusaha untuk meniadakan atau mengelakkan perasaan tidak suka itu. Jadi motivasi dapat dirangsang oleh faktor dari luar, tetapi motivasi itu tumbuh dari dalam diri seseorang. Lingkungan merupakan salah satu faktor dari luar yang dapat menumbuhkan motivasi dalam diri seseorang untuk belajar. Dalam proses pembelajaran tradisional yang menggunakan pendekatan ekspositori kadang-kadang unsur motivasi terlupakan oleh guru. Guru seakan-akan memaksakan siswa menerima materi yang disampaikannya. Keadaan ini tidak menguntungkan karena siswa tidak dapat belajar secara optimal yang tentunya pencapaian hasil belajar juga tidak akan optimal. Pandangan modern tentang proses pembelajaran menempatkan motivasi sebagai salah satu aspek penting dalam membangkitkan motivasi belajar siswa.

Keberhasilan belajar peserta didik dalam proses pembelajaran sangat dipengaruhi oleh motivasi yang ada pada dirinya. Indikator kualitas pembelajaran salah satunya adalah adanya motivasi yang tinggi dari para peserta didik. Peserta didik yang memiliki motivasi belajar yang tinggi terhadap pembelajaran maka mereka akan tergerak atau tergugah untuk memiliki keinginan melakukan sesuatu yang dapat memperoleh hasil atau tujuan tertentu. Menurut Kompri Kompri (2015), motivasi belajar merupakan segi kejiwaan yang mengalami perkembangan, artinya terpengaruh oleh kondisi fisiologis dan kematangan psikologis siswa. Beberapa unsur yang mempengaruhi motivasi dalam belajar yaitu: a) 
cita-cita dan aspirasi siswa. Cita-cita akan memperkuat motivasi belajar siswa baik instrinsik maupun ekstrinsik. b) kemampuan siswa. Keingianan seorang anak perlu dibarengi dengan kemampuan dan kecakapan dalam pencapaiannya. c) kondisi siswa. Kondisi siswa yang meliputi kondisi jasmani dan ruhani. Contoh: seorang siswa yang sedang sakit akan mengganggu perhatian para siswa. d) Kondisi lingkungan siswa. Lingkungan siswa dapat berupa lingkungan alam, tempat tinggal, pergaulan sebaya dan kehidupan bermasyarakat.

Untuk mengetahui kekuatan motivasi belajar siswa, dapat dilihat dari berbagai indikator, di antaranya: kuatnya kemauan untuk berbuat, jumlah waktu yang disediakan untuk belajar, kerelaan meninggalkan kewajiban atau tugas lain, ketekunan dalam mengerjakan tugas, Suprihatin (2015), tekun menghadapi tugas, ulet menghadapi kesulitan (tidak lekas putus asa), menunjukkan minat terhadap bermacammacam masalah orang dewasa, lebih sering bekerja mandiri, cepat bosan pada tugas rutin, dan dapat mempertahankan pendapatnya. Manuhutu (2015). Sedangkan faktor-faktor yang mempengaruhi motivasi belajar antara lain: a) citacita/aspirasi siswa, b) kemampuan siswa, c) kondisi siswa dan lingkungan, d) unsur-unsur dinamis dalam belajar, e) upaya guru dalam membelajarkan siswa. Emda (2018).

Sedangkan menurut Slameto dalam Emda (2018), seorang individu membutuhkan suatu dorongan atau motivasi belajar sehingga sesuatu yang diinginkan dapat tercapai, dalam hal ini ada beberapa faktor yang mempengaruhi belajar antara lain: a) Faktor Individual, seperti kematangan atau pertumbuhan, kecerdasan, latihan, motivasi, dan faktor pribadi. b) Faktor Sosial, seperti keluarga atau keadaan rumah tangga, guru dan cara mengajarnya, alat-alat dalam belajar, dan motivasi sosial. Adapun faktor lain yang dapat mempengaruhi belajar menurut Slameto dalam Hapnita (2018) adalah: a) Faktor Intern: faktor jasmaniah, psikologis, dan kelelahan. b) Faktor Ekstern: faktor keluarga, sekolah, dan masyarakat.

Berdasarkan beberapa pendapat diatas, motivasi dapat diartikan sebagai kekuatan (energi) seseorang yang dapat menimbulkan tingkat kemauan dalam melaksanakan suatu kegiatan. Kemauan baik yang bersumber dari dalam diri individu itu sendiri (motivasi intrinsik) maupun dari luar individu (motivasi ekstrinsik). Seberapa kuat motivasi yang dimiliki individu akan banyak menentukan kualitas perilaku yang ditampilkannya. Baik dalam konteks belajar, bekerja maupun dalam kehidupan lainnya.

Disamping itu, tak lepas dari situasi pandemic yang melanda dan juga perkembangan era disrupsi teknologi informasi dan komunikasi (TIK), pembelajaran daring adalah pembelajaran yang memungkinkan untuk mudah dijangkau mulai dari kalangan guru hingga siswa. Pasalnya, mayoritas masyarakat di Indonesia sudah tidak asing lagi dengan pemakaian teknologi informasi seperti gawai dan internet. Penggunaan internet untuk keperluan pendidikan yang semakin meluas terutama di negara-negara maju, merupakan fakta yang menunjukkan bahwa dengan media ini memang dimungkinkan diselenggarakannya proses belajar mengajar yang lebih efektif. Siswanto et al., (2017) Sebagai media yang diharapkan akan menjadi bagian dari suatu proses belajar mengajar di sekolah terutama dalam pembelajaran jarak jauh, internet harus mampu memberikan dukungan bagi tereselenggaranya proses komunikasi interaktif antara guru dengan siswa sebagaimana yang dipersyaratkan dalam suatu kegiatan pembelajaran. Kondisi yang harus mampu didukung oleh internet tersebut terutama berkaitan dengan strategi pembelajaran yang akan dikembangkan, dan jika dijabarkan secara sederhana, bisa diartikan sebagai kegiatan komunikasi yang dilakukan untuk mengajak siswa mengerjakan tugastugas dan membantu siswa dalam memperoleh pengetahuan yang dibutuhkan dalam rangka mengerjakan tugas-tugas tersebut. Hernawati \& UNY (2012).

Salah satu pemanfaatan internet dalam dunia pendidikan adalah pembelajaran jarak jauh atau distance learning. Terdapat berbagai istilah untuk mengemukakan gagasan mengenai pembelajaran jarak jauh dengan memanfaatkan internet, yaitu: online learning, e-learning (pembelajaran elektronik), internet-enable learning, virtual learning, virtual classroom atau web based learning. Siahaan (2003)

Terdapat beberapa hal penting sebagai persyaratan kegiatan pembelajaran online, yaitu: 1) Kegiatan pembelajaran dilakukan melalui pemanfaatan jaringan (internet), 2) tersedianya dukungan layanan belajar yang dapat dimanfaatkan oleh siswa, 3) tersedianya dukungan layanan tutor (konsultan) yang dapat membantu peserta belajar apabila mengalami kesulitan, 4) tersedianya lembaga yang menyelenggarakan/mengelola kegiatan e-learning, 5) sikap positif dari siswa dan guru terhadap teknologi komputer dan internet, 6) rancangan sistem pembelajaran yang dapat dipelajari/diketahui oleh mahasiswa, 7) sistem evaluasi terhadap kemajuan atau perkembangan belajar mahasiswa, 8) mekanisme umpan balik yang dikembangkan oleh lembaga penyelenggara/pengelola. Siahaan (2003). Secara sederhana, Brown (2000) mengatakan bahwa pembelajaran elektronik (pembelajaran online) merupakan kegiatan pembelajaran yang memanfaatkan jaringan (internet, LAN, WAN) sebagai metode penyampaian, interaksi dan fasilitasi serta didukung oleh berbagai bentuk layanan belajar lainnya.

Fungsi pembelajaran online menurut Siahaan (2003) ada 3 fungsi terhadap kegiatan pembelajaran di kelas (classroom instruction), yaitu sebagai: 1) Suplemen (Tambahan), sebagai suplemen jika siswa mempunyai kebebasan memilih, apakah akan memanfaatkan materi pembelajaran online atau tidak. Dalam hal ini tidak ada kewajiban bagi siswa untuk mengakses materi pembelajaran online. 2) Komplemen (Pelengkap), sebagai komplemen jika materi pembelajaran online diprogramkan untuk melengkapi materi pembelajaran yang diterima siswa didalam kelas. Materi pembelajaran online diprogramkan untuk menjadi materi reinforcement (pengayaan) atau remidial bagi siswa didalam mengikuti kegiatan pembelajaran konvensional. 3) Substitusi (Pengganti), sebagai substitusi jika materi pembelajaran online diprogramkan untuk menggantikan materi pembelajaran yang diterima siswa di kelas.

Alternatif model pembelajaran manapun yang akan dipilih siswa tidak menjadi masalah dalam penulisan. Karena ketiga model penyajian materi pembelajaran mendapatkan pengakuan atau penilaian yang sama. Jika siswa dapat menyelesaikan program pembelajarannya dan lulus melalui cara konvensional atau sepenuhnya melalui internet, atau bahkan melalui perpaduan kedua model ini, maka institusi 
penyelenggara pendidikan akan memberikan pengakuan yang sama. Keadaan yang sangat fleksibel ini dinilai sangat membantu siswa untuk mempercepat penyelesaian sekolah mereka. Waryanto (2006).

\section{Dampak Kebijakan Pembelajaran Daring Terhadap Motivasi Belajar Siswa Pada Era Pandemi Covid-19}

Diagram 2. Diagram Penelitian Kota-kota di Jawa Timur yang Melaksanakan Pembelajaran Daring.

\section{[Figure 2 about here.]}

Melalui kuesioner penulisan menggunakan google from yang dirilis mulai tanggal 5 Juli - 23 Juli 2020, didapatkan hasil data sebagai berikut yang akan dijelaskan secara naratif oleh penulis. Per tanggal 23 Juli 2020, telah didapatkan data responden sebanyak 98 orang, 15 kabupaten/kota di Jawa Timur, dan 38 sekolah yang tersebar di 15 kabupaten/kota tersebut. Rincian dari 15 kabupaten/kota tersebut adalah: Surabaya, Sidoarjo, Gresik, Lamongan, Tuban, Jember, Mojokerto, Bojonegoro, Magetan, Madiun, Jombang, Bondowoso, Banyuwangi, Pasuruan, Malang. Sedangkan rincian dari sekolah SMA/MA sederajat pada 15 kabupaten/kota tersebut adalah: MAN 2 Gresik, MAN 2 Tuban, MAN 1 Jember, MAN Sidoarjo, SMAN 1 Puri, MAN 2 Kota Madiun, MAN Surabaya, MAN 3 Jombang, SMKN 1 Lamongan, SMA Muhammadiyah 10 GKB, SMAN 18 Surabaya, SMAN 1 Kedungagem, SMAN 4 Sidoarjo, SMA Negeri 1 Barat, MAN 1 Gresik, MAN 2 Gresik, SMA Khadijah Surabaya, MA Ma'arif NU As-Sa'adah, SMA 2 Mejayan, SMKN 3 Madiun, SMA As-Sa'adah, MA AlAnwar, SMAN 1 Jombang, SMAN 18 Surabaya, SMK Gadjah Mada, SMK YPM 3 Taman, MAN 2 Lamongan, SMAN 1 Gondangwetan, SMAN 1 Surakarta, SMAN 3 Jombang, SMA Walisongo, MA Roudlotul Muta'aimin, SMA Progresif Bumi Sholawat, MAN 2 Mojokerto, MA Unggulan KH Abdul Wahab Hasbulloh, SMK Ketintang, MAN 1 Jombang, dan SMK Telkom. Beberapa hasil rincian pertanyaan pada kuesioner penulisan tersebut penulis sajikan pada tabel berikut:

\section{[Table 1 about here.]}

Dari hasil perolehan berdasarkan data pada Tabel 1 kuesioner tersebut dapat disimpulkan bahwa siswa/siswi SMA/MA sederajat di Jawa Timur selama belajar daring di masa pandemi ini telah mengerjakan tugas sekolah dengan baik dan tepat waktu, dengan prosentase angka hampir separuh yakni 47,5\%. Sedangkan, sisanya siswa/siswi SMA/MA sederajat di Jawa Timur tidak dapat mengerjakan tugas dengan baik dan tepat waktu pada masa pandemi. Alasan yang diungkapkan siswa yang belum bisa mengerjakan tugas dengan baik dan tepat waktu sebagaimana yang telah termaktub dalam hasil jawaban kuesioner penulisan pada bagian pertanyaan terbuka yakni pada saat pembelajaran daring, guru lebih sering memberikan tugas dari pada menjelaskan materi. Akibatnya, tugas yang diberikan pada siswa tersebut masih ada yang tidak efektif untuk dilakukan beberapa siswa. Alasan lainnya adalah berhubung dengan kuota internet. Beberapa siswa mengungkapkan alasan bahwa mereka terkendala oleh sinyal yang lemot dan paket kuota yang menipis, sehingga dalam menyelesaikan tugas yang diberikan oleh guru masih belum maksimal. Dalam segi keantusiasan siswa, ada sekitar 39,6\% siswa yang antusias selama mengikuti pembelajaran daring di masa pandemi, termasuk dalam memperhatikan pembelajaran saat guru menerangkan via teleconverance sampai pada menambah jam belajar di luar jam pembelajaran bersama guru. Sedangkan sisanya lebih banyak mereka menyampaikan keluhan serupa, yakni guru pada saat mengajar daring tidak banyak memberikan penjelasan materi pelajaran yang sampai pada pemahaman siswa. Akibatnya, siswa menjadi tidak antusias dalam mengikuti pembelajaran dan berdampak pada motivasi belajar mereka.

Sejalan dengan itu, ciri-ciri siswa yang memiliki motivasi belajar diklasifikasikan sebagai berikut: a) adanya hasrat dan ingin untuk berhasil, b) adanya dorongan dan kebutuhan dalam belajar, c) adanya harapan dan cita-cita di masa depan, d) adanya kegiatan yang menarik dalam belajar, e) adanya lingkungan belajar yang kondusif, sehingga memungkinkan seorang siswa dapat belajar dengan baik. Darmawati (2017). Pada poin a,b,c penulis menganggap bahwa setiap peserta didik memiliki keinginan dan cita-cita untuk berhasil atau sukses di masa depan diiringi dengan adanya kebutuhan untuk meraih keberhasilan tersebut dengan cara belajar (bersekolah). Namun pada poin d dan e, penulis menyimpulkan bahwa disinilah letak pendidik atau guru untuk mewujudkan motivasi belajar peserta didik. Yakni dengan mengadakan kegiatan yang menarik dalam pembelajaran dan menciptakan suasana atau lingkungan belajar yang kondusif, sehingga memungkinkan siswa untuk dapat belajar dengan optimal.

Pada pertanyaan "Selama masa belajar daring ini, saya tidak menyontek teman atau mencari jawaban dari google saat mengerjakan tugas dari guru", terdapat sekitar $35,4 \%$ jawaban keragu-raguan dan $48 \%$ jawaban tidak setuju. Hasil data ini menunjukkan bahwa pembelajaran daring yang dilakukan selama pandemi menyebabkan penurunan intensitas belajar siswa yang akan mempengaruhi pula terhadap motivasi belajar mereka. Sejalan dengan itu, Sardiman dalam Solina Solina et al., (2013) menyatakan bahwa ciri-ciri siswa yang memiliki motivasi belajar yaitu: a) tekun menghadapi tugastugas dan dapat bekerja terus-menerus sampai pekerjaannya selesai, b) ulet dan tidak mudah putus asa dalam menghadapi kesulitan, c) memungkinkan memiliki minat terhadap bermacam-macam masalah, d) lebih sering bekerja secara mandiri, e) cepat bosan dengan tugas-tugas rutin, f) jika sudah yakin, dapat mempertahankan pendapatnya, g) tidak akan melepaskan sesuatu yang telah diyakini, h) sering mencari dan memecahkan masalah soal-soal. Mencontek merupakan budaya tabu yang sudah menjamur pada ranah pendidikan. Selama proses pembelajaran berlangsung, sebagai pendidik sebisa mungkin untuk mengurangi dan membasmi budaya kecurangan semacam ini terjadi pada peserta didik. Namun, pada pembelajaran daring yang dilakukan selama pandemi, pendidik sulit untuk mengontrol budaya mencontek tersebut. Akibatnya, berpengaruh pada nilai dan hasil evaluasi peserta didik yang dinilai kurang transparan, karena antara siswa yang pintar dan kurang pintar nilainya tidak jauh berbeda. Penulis 
menilai bahwa hasil penilaian juga berpengaruh terhadap motivasi belajar siswa. Jika sudah tidak ada kontrol dari guru, siswa leluasa melakukan kecurangan, dan nilai yang didapat hanya dilihat dari performa jawaban soal yang benar, maka siswa bisa saja tidak lagi punya motivasi belajar yang lebih tinggi dan jujur.

Dari segi psikis anak, ada sekitar $62,7 \%$ siswa dari hasil data kuesioner penulisan yang selama mengikuti pembelajaran daring merasa bosan dan stress. Ada yang mengungkapkan bahwa guru hanya memberikan tugas-tugas saja selama pembelajaran daring tanpa diiringi dengan penjelasan materi pembelajaran dan pemberian modul online, sehingga siswa merasa bosan dan tidak menikmati pembelajaran tersebut. Ada juga yang mengungkapkan bahwa mereka merasa stress karena terlalu lama berada di rumah. Mereka mengaku rindu suasana sekolah yang normal, dimana mereka bisa bertemu dengan teman-teman dan guruguru mereka dalam satu kelas dan bertatap muka secara langsung.

Sekitar 70,7\% siswa juga mengungkapkan bahwa dalam pembelajaran daring mereka tidak dapat dengan mudah memahami penjelasan yang diberikan guru. Namun pada opsi pertanyaan "Guru sangat maksimal dalam memberikan pengajaran pada saat pembelajaran daring", ada sekitar $62,7 \%$ yang menyatakan setuju. Menurut penulis, hal ini menunjukkan bahwa dalam hal pengajaran, guru telah berusaha semaksimal mungkin untuk melakukan pembelajaran daring pada situasi pandemi sesuai dengan kebijakan pemerintah. Namun, tidak dapat dinafikan bahwa kebijakan belajar daring tersebut belum sepenuhnya berjalan optimal sebagaimana yang diharapkan. Sejalan dengan itu, Subarno (2019) menyebutkan faktor-faktor yang mempengaruhi motivasi belajar yaitu: 1) Faktor Internal, meliputi: Faktor Fisik. Faktor fisik meliputi nutrisi (gizi), kesehatan, dan fungsi-fungsi fisik (terutama panca indera). 2) Faktor Psikologis. Faktor psikologis berhubungan dengan aspek-aspek yang mendorong atau menghambat aktivitas belajar pada siswa.3) Faktor Eksternal (yang berasal dari lingkungan), meliputi: Faktor Non-Sosial. Faktor non-sosial meliputi keadaan udara (cuaca panas atau dingin), waktu (pagi, siang, malam), tempat (sepi, bising, atau kualitas sekolah tempat belajar), sarana dan prasarana atau fasilitas belajar. 4) Faktor Sosial. Faktor sosial adalah faktor manusia (guru, konselor, dan orang tua), baik yang hadir secara langsung maupun tidak langsung (foto atau suara). Proses belajar akan berlangsung dengan baik, apabila guru mengajar dengan cara menyenangkan, seperti bersikap ramah, memberi perhatian pada semua siswa, serta selalu membantu siswa yang mengalami kesulitan belajar. Pada saat di rumah siswa tetap mendapat perhatian orang tua, baik material dengan menyediakan sarana prasarana belajar guna membantu dan mempermudah siswa belajar di rumah.

Dari penjelasan tersebut dapat disimpulkan bahwa baik faktor internal maupun eksternal memiliki pengaruh yang kuat terhadap motivasi belajar siswa. Dalam hal ini, penulis memfokuskan faktor psikologis dan faktor sosial yang mempengaruhi motivasi belajar siswa, bahwasanya hasil data penulisan tersebut menunjukkan relevansi dengan teori yang didapat, yakni tingkat kebosanan dan rasa stress yang dialami siswa masuk dalam kategori faktor psikologis yang mana itu sangat mempengaruhi motivasi belajar siswa. Begitupun dengan intensitas pemahaman siswa terhadap pembelajaran yang diberikan oleh guru termasuk dalam kategori faktor sosial, karena guru terlibat dalam pemberian pengetahuan dan wawasan, juga karena sistem pembelajaran daring yang terkonsep kurang matang, sehingga hal itu mempengaruhi motivasi belajar mereka.

Adapun pada pernyataan "Sejak masa pembelajaran daring, pengetahuan saya lebih meningkat dibanding pengetahuan yang saya miliki semasa pembelajaran luring" ada sekitar 53,5\% yang menyatakan tidak setuju, 28,3\% memilih ragu-ragu, dan 22,2\% memilih setuju. Hal ini relevan dengan pernyataan yang sebelumnya, bahwa guru selama mengajar dengan sistem daring kurang dapat berkomunikasi secara optimal dengan siswa. Akibatnya banyak siswa yang masih kurang memahami penjelasan materi dari guru dan berakibat pada intensitas pengetahuan mereka. Ada salah satu siswa mengungkapkan pada kolom kuesioner pada pertanyaan terbuka, yakni "Kalau bisa dimaksimalkan lagi sistemnya. Entah itu masuk secara bergantian guna menghindari kerumunan. Intinya tidak efektif jika belajarnya daring. Merasa tidak dapat apa-apa dari pembelajarannya. Malah dapatnya ketika baca buku atau baca media lain ketimbang pembelajaran secara daring". Pernyataan tersebut menunjukkan bahwa pengetahuan yang dimiliki siswa pada saat pembelajaran sangat menurun dibandingkan ketika pembelajaran luring.

\section{KESIMPULAN}

Dari hasil penulisan dapat disimpulkan bahwa kebijakan pembelajaran daring pada saat pandemi Covid-19 memiliki dampak negatif dan positif terhadap motivasi belajar siswa belajar SMA/MA sederajat di Jawa Timur. Akan tetai dampak negatif lebih dominan dari pada dampak positif. Agar dampak negatif kebijakan pembelajaran daring terhadap motivasi belajar siswa tidak berlarut-larut dan semakin memburuk kondisi pendidikan di Indonesia, maka hasil dari penelitian ini dapat menjadi tolok ukur pemerintah dalam mengevaluasi dan memperbaiki kebijakan terkait pembelajaran di masa pandemi Covid-19 ini. Di antaranya, hasil oenelitian ini dapat dijadikan usulan pertimbangan pemerintah dalam membuat kebijakan lanjutan terkait pembelajaran daring dengan menyesuaikan latar belakang sosial masyarakat yang beragam dan memperhatikan keadaan psikis siswa yang telah lama mengikuti pembelajaran daring sejak pandemi Covid-19. Selain itu, hasil openelitian ini rekomendasi kepada pemerintah terkait jangka waktu pemberlakuan pembelajaran daring di SMA/MA, yakni apakah kebijakan pembelajaran daring ini akan diperpanjang, dihentikan atau divariasikan dengan menambahkan pembelajaran luring dengan bentuk Hybrid learning/blended learning berdasarkan wilayah sekolah atau kondisi status pandemi atau zona (merah, orange, kuning, hijau) di wilayah sekolah tersebut. 


\section{REFERENCES}

Abou-Khalil, V., Helou, S., Khalifé, E., Chen, M. A., Majumdar, R., \& Ogata, H (2021). Emergency online learning in low-resource settings: Effective student engagement strategies. Education Sciences, 11(1), 1-18. https://doi.org/10.3390/educsci11010024

Al-Taweel, F. B., Abdulkareem, A. A., Gul, S. S., \& Alshami, M. L. (2021). Evaluation of technology-based learning by dental students during the pandemic outbreak of coronavirus disease 2019. European Journal of Dental Education, 25(1), 183-190. https://doi.org/10.1111/eje.12589

Arifa, F. N. (2020). Tantangan Pelaksanaan Kebijakan Belajar Dari Rumah Dalam Masa Darurat Covid-19. Info Singkat;Kajian Singkat Terhadap Isu Aktual Dan Strategis, XII(7/I), 6 http://berkas.dpr.go.id/puslit/files/info_singkat/Info Singkat-XII-7-I-P3DIApril-2020-1953.pdf

Bibi, S., \& Jati, H. (2015). Efektivitas model blended learning terhadap motivasi dan tingkat pemahaman mahasiswa mata kuliah algoritma dan pemrograman. Jurnal Pendidikan Vokasi, 5(1), 74-87.

Cahyani, A., Listiana, I. D., \& Larasati, S. P. D. (2020). Motivasi Belajar Siswa SMA pada Pembelajaran Daring di Masa Pandemi Covid-19. IQ (Ilmu AlQur'an): Jurnal Pendidikan Islam, 3(01), 123-140. https://doi.org/10.37542/iq.v3i01.57

Darmawati, J. (2017), pengaruh motivasi belajar dan gaya belajar terhadap prestasi belajar ekonomi siswa SMA negeri di kota Tuban. Jurnal Ekonomi Pendidikan Dan Kewirausahaan, 1(1), 79-90.

Emda, A. (2018). Kedudukan motivasi belajar siswa dalam pembelajaran Lantanida Journal, 5(2), 172-182.

Engkus, E., Suparman, N., Tri Sakti, F., \& Saeful Anwar, H. (2020). Covid-19: Kebijakan mitigasi penyebaran dan dampak sosial ekonomi di Indonesia. LP2M.

Gunawan, B. (2020). Analisis Yuridis Pendidikan Jarak Jauh dalam Perspektif Hak Asasi Manusia dalam Undang-Undang Dasar NRI 1945 pada Masa Pandemi Covid-19 di Indonesia. Jurnal HAM, 11(3), 387. https://doi.org/10.30641/ham.2020.11.387-404

Hadari Nawawi, H. M. (1996). Penelitian Terapan. Yogyakarta: Gajahmada University Press

Hapnita, W. (2018). Faktor Internal Dan Eksternal Yang Dominan Mempengaruhi Hasil Belajar Menggambar Dengan Perangkat Lunak Siswa Kelas Xi Teknik Gambar Bangunan Smk N 1 Padang Tahun 2016/2017. CIVED (Journal of Civil Engineering and Vocational Education), 5(1).

Hernawati, K., \& UNY, J. (2012). Pemanfaatan Sumber Belajar Internet Berbasis Edutainment dalam Pembelajaran Matematika Siswa Sekolah Dasar. Prosiding Seminar Nasional Matematika UNY.

https://bebas.kompas. id/baca/riset/2020/03/26/suka- duka-belajar-di-rumah/, diakses 31 M. 2020. (n.d.). "Suka Duka Belajar di Rumah",.

Inah, E. N., \& Khairunnisa, A. (2019). Hubungan Motivasi Belajar Dengan Prestasi Belajar Bahasa Arab Mahasiswa Bidikmisi. Al-TA'DIB: Jurnal Kajian Ilmu Kependidikan, 12(1), 36-51.

Isman. (2017). Pembelajaran Moda dalam Jaringan (Moda Daring). The Progressive and Fun Education Seminar, 586-588.

Kompri, M. P. I. (2015). Motivasi Pembelajaran Perspektif guru dan siswa. Bandung PT Remaja Rosdakarya Offset.

Lesmana, R., Sunardi, N., \& Tumanggor, M. (2020). Pelatihan Manajemen dalam Meningkatkan Motivasi Siswa dan Guru SDN 84 Rejang Lebong. Jurnal Abdi Masyarakat Humanis, 1(2).

Magdalena, I., Nokhriyana, A. D., Sipayung, K. N. S., \& Tsania, S. (2020) Dampak Covid-19 terhadap Implementasi Pembelajaran Daring di Sekolah Dasar. BINTANG, 2(3), 323-333.

Manuhutu, S. (2015). Analisis Motivasi Belajar Internal Siswa Program Akselerasi Kelas VIII SMP Negeri 6 Ambon. PROMOSI: Jurnal Program Studi Pendidikan Ekonomi, 3(1).

Muhammad, M. (2017). Pengaruh Motivasi Dalam Pembelajaran. Lantanida Journal, 4(2), 87. https://doi.org/10.22373/lj.v4i2.1881

Nakayama, M., Yamamoto, H., \& Santiago, R. (2007). Relationship between learner characteristics and learning performance in hybrid courses among Japanese students. Proceedings of the International Conference on ELearning, ICEL, 2007-Janua(3), 341-349.

Purmadi, A., \& Hadi, M. S. (2018). Pengembangan Kelas Daring Dengan Penerapan Hybrid Learning Menggunakan Chamilo Pada Matakuliah Pendidikan Kewarganegaraan. Edcomtech Jurnal Kajian Teknologi ..., 135140. http://journal2.um.ac.id/index.php/edcomtech/article/view/5467

Samudera, W. (2020). Dampak Pandemi Covid-19 Dalam Bidang Pendidikan Di Kota Mataram. Indonesian Journal of Teacher Education, 1(3), 154-158.

Sanjaya, W. (2010). Kurikulum dan Pembelajaran, Teori dan Praktek Pengembangan Kurikulum KTSP. Jakarta: Kencana.

Siahaan, S. (2003). E-Learning (Pembelajaran Elektronik) Sebagai Salah Satu Alternatif Kegiatan Pembelajaran. Jurnal Pendidikan Dan Kebudayaan, 9(42), 303-321

Siswanto, S., Degeng, N. S., \& Sudarmiatin, S. (2017). PEMANFAATAN INTERNET SEBAGAI SUMBER BELAJAR ILMU PENGETAHUAN
SOSIAL. Prosiding Seminar Nasional Mahasiswa Kerjasama Direktorat Jenderal Guru Dan Tenaga Kependidikan Kemendikbud 2016.

Solina, W., Erlamsyah, E., \& Syahniar, S. (2013). Hubungan Antara Perlakuan Orangtua Dengan Motivasi Belajar Siswa Disekolah. Konselor, 2(1).

Subarno, A. (n.d.). Pengaruh Gaya Mengajar Guru dan Perhatian Orang Tua terhadap Motivasi Belajar Siswa di SMK Batik 1 Surakarta. JIKAP (Jurnal Informasi Dan Komunikasi Administrasi Perkantoran), 3(4), 31-39.

Sugihamretha, I. D. G. (2020). Respon Kebijakan: Mitigasi Dampak Wabah Covid19 Pada Sektor Pariwisata. Jurnal Perencanaan Pembangunan: The Indonesian Journal of Development Planning, 4(2), 191-206. https://doi.org/10.36574/jpp.v4i2.113

Sukmadinata; Nana Syaodih. (2013). Metode Penelitian Pendidikan. Bandung : PT Remaja Rosdakarya.

Suprihatin, S. (2015). Upaya guru dalam meningkatkan motivasi belajar siswa. Jurnal Pendidikan Ekonomi UM Metro, 3(1), 73-82.

Waryanto, N. H. (2006). Online learning sebagai salah satu inovasi pembelajaran. Jurnal Phitagoras, 2(1).

Yunitasari, R., \& Hanifah, U. (2020). Pengaruh Pembelajaran Daring terhadap Minat Belajar Siswa pada Masa COVID 19. Edukatif: Jurnal Ilmu Pendidikan, 2(3), 232-243. https://doi.org/10.31004/edukatif.v2i3.142

Abou-Khalil, V., Helou, S., Khalifé, E., Chen, M. A., Majumdar, R., \& Ogata, H. (2021). Emergency online learning in low-resource settings: Effective student engagement strategies. Education Sciences, 11(1), 1-18. https://doi.org/10.3390/educsci11010024

Al-Taweel, F. B., Abdulkareem, A. A., Gul, S. S., \& Alshami, M. L. (2021). Evaluation of technology-based learning by dental students during the pandemic outbreak of coronavirus disease 2019. European Journal of Dental Education, 25(1), 183-190. https://doi.org/10.1111/eje.12589

Arifa, F. N. (2020). Tantangan Pelaksanaan Kebijakan Belajar Dari Rumah Dalam Masa Darurat Covid-19. Info Singkat;Kajian Singkat Terhadap Isu Aktual Dan Strategis, XII(7/I), 6. http://berkas.dpr.go.id/puslit/files/info_singkat/Info Singkat-XII-7-I-P3DI-April-2020-1953.pdf

Bibi, S., \& Jati, H. (2015). Efektivitas model blended learning terhadap motivasi dan tingkat pemahaman mahasiswa mata kuliah algoritma dan pemrograman. Jurnal Pendidikan Vokasi, 5(1), 74-87.

Cahyani, A., Listiana, I. D., \& Larasati, S. P. D. (2020). Motivasi Belajar Siswa SMA pada Pembelajaran Daring di Masa Pandemi Covid-19. IQ (Ilmu AlQur'an): Jurnal Pendidikan Islam, 3(01), 123-140. https://doi.org/10.37542/iq.v3i01.57

Darmawati, J. (2017). pengaruh motivasi belajar dan gaya belajar terhadap prestasi belajar ekonomi siswa SMA negeri di kota Tuban. Jurnal Ekonomi Pendidikan Dan Kewirausahaan, 1(1), 79-90.

Emda, A. (2018). Kedudukan motivasi belajar siswa dalam pembelajaran Lantanida Journal, 5(2), 172-182.

Engkus, E., Suparman, N., Tri Sakti, F., \& Saeful Anwar, H. (2020). Covid-19: Kebijakan mitigasi penyebaran dan dampak sosial ekonomi di Indonesia. LP2M.

Gunawan, B. (2020). Analisis Yuridis Pendidikan Jarak Jauh dalam Perspektif Hak Asasi Manusia dalam Undang-Undang Dasar NRI 1945 pada Masa Pandemi Covid-19 di Indonesia Jurnal HAM, 11(3), 387. https://doi.org/10.30641/ham.2020.11.387-404

Hadari Nawawi, H. M. (1996). Penelitian Terapan. Yogyakarta: Gajahmada University Press.

Hapnita, W. (2018). Faktor Internal Dan Eksternal Yang Dominan Mempengaruhi Hasil Belajar Menggambar Dengan Perangkat Lunak Siswa Kelas Xi Teknik Gambar Bangunan Smk N 1 Padang Tahun 2016/2017. CIVED (Journal of Civil Engineering and Vocational Education), 5(1).

Hernawati, K., \& UNY, J. (2012). Pemanfaatan Sumber Belajar Internet Berbasis Edutainment dalam Pembelajaran Matematika Siswa Sekolah Dasar. Prosiding Seminar Nasional Matematika UNY.

https://bebas.kompas. id/baca/riset/2020/03/26/suka- duka-belajar-di-rumah/, diakses 31 M. 2020. (n.d.). "Suka Duka Belajar di Rumah",

Inah, E. N., \& Khairunnisa, A. (2019). Hubungan Motivasi Belajar Dengan Prestasi Belajar Bahasa Arab Mahasiswa Bidikmisi. Al-TA’DIB: Jurnal Kajian Ilmu Kependidikan, 12(1), 36-51.

Isman. (2017). Pembelajaran Moda dalam Jaringan (Moda Daring). The Progressive and Fun Education Seminar, 586-588.

Kompri, M. P. I. (2015). Motivasi Pembelajaran Perspektif guru dan siswa. Bandung PT Remaja Rosdakarya Offset.

Lesmana, R., Sunardi, N., \& Tumanggor, M. (2020). Pelatihan Manajemen dalam Meningkatkan Motivasi Siswa dan Guru SDN 84 Rejang Lebong. Jurnal Abdi Masyarakat Humanis, 1(2)

Magdalena, I., Nokhriyana, A. D., Sipayung, K. N. S., \& Tsania, S. (2020) Dampak Covid-19 terhadap Implementasi Pembelajaran Daring di Sekolah Dasar. BINTANG, 2(3), 323-333.

Manuhutu, S. (2015). Analisis Motivasi Belajar Internal Siswa Program Akselerasi Kelas VIII SMP Negeri 6 Ambon. PROMOSI: Jurnal Program Studi Pendidikan Ekonomi, 3(1)

Muhammad, M. (2017). Pengaruh Motivasi Dalam Pembelajaran. Lantanida 
Journal, 4(2), 87. https://doi.org/10.22373/lj.v4i2.1881

Nakayama, M., Yamamoto, H., \& Santiago, R. (2007). Relationship between learner characteristics and learning performance in hybrid courses among Japanese students. Proceedings of the International Conference on ELearning, ICEL, 2007-Janua(3), 341-349.

Purmadi, A., \& Hadi, M. S. (2018). Pengembangan Kelas Daring Dengan Penerapan Hybrid Learning Menggunakan Chamilo Pada Matakuliah Pendidikan Kewarganegaraan. Edcomtech Jurnal Kajian Teknologi ..., 135140. http://journal2.um.ac.id/index.php/edcomtech/article/view/5467

Samudera, W. (2020). Dampak Pandemi Covid-19 Dalam Bidang Pendidikan Di Kota Mataram. Indonesian Journal of Teacher Education, 1(3), 154-158.

Sanjaya, W. (2010). Kurikulum dan Pembelajaran, Teori dan Praktek Pengembangan Kurikulum KTSP. Jakarta: Kencana.

Siahaan, S. (2003). E-Learning (Pembelajaran Elektronik) Sebagai Salah Satu Alternatif Kegiatan Pembelajaran. Jurnal Pendidikan Dan Kebudayaan, 9(42), 303-321.

Siswanto, S., Degeng, N. S., \& Sudarmiatin, S. (2017). PEMANFAATAN INTERNET SEBAGAI SUMBER BELAJAR ILMU PENGETAHUAN SOSIAL. Prosiding Seminar Nasional Mahasiswa Kerjasama Direktorat Jenderal Guru Dan Tenaga Kependidikan Kemendikbud 2016.

Solina, W., Erlamsyah, E., \& Syahniar, S. (2013). Hubungan Antara Perlakuan Orangtua Dengan Motivasi Belajar Siswa Disekolah. Konselor, 2(1).

Subarno, A. (n.d.). Pengaruh Gaya Mengajar Guru dan Perhatian Orang Tua terhadap Motivasi Belajar Siswa di SMK Batik 1 Surakarta. JIKAP (Jurnal Informasi Dan Komunikasi Administrasi Perkantoran), 3(4), 31-39.

Sugihamretha, I. D. G. (2020). Respon Kebijakan: Mitigasi Dampak Wabah Covid-19 Pada Sektor Pariwisata. Jurnal Perencanaan Pembangunan: The
Indonesian Journal of Development Planning, 4(2), 191-206. https://doi.org/10.36574/jpp.v4i2.113

Sukmadinata; Nana Syaodih. (2013). Metode Penelitian Pendidikan. Bandung : PT Remaja Rosdakarya.

Suprihatin, S. (2015). Upaya guru dalam meningkatkan motivasi belajar siswa. Jurnal Pendidikan Ekonomi UM Metro, 3(1), 73-82.

Waryanto, N. H. (2006). Online learning sebagai salah satu inovasi pembelajaran. Jurnal Phitagoras, 2(1).

Yunitasari, R., \& Hanifah, U. (2020). Pengaruh Pembelajaran Daring terhadap Minat Belajar Siswa pada Masa COVID 19. Edukatif: Jurnal Ilmu Pendidikan, 2(3), 232-243. https://doi.org/10.31004/edukatif.v2i3.142

ConflictofInterestStatement:The authorsdeclare that theresearchwas conducted in the absence of any commercial or financial relationships that could be construed as a potential conflict of interest.

Copyright (C2021Umi Hanifah, Nida Anisah Firdaus. Thisisanopen-accessarticle dis- tributed under the terms of the Creative Commons Attribution License (CC BY). The use, distribution or reproduction in other forums is permitted, provided the original author(s) and the copyright owner(s) are credited and that the original publication in this journal is cited, in accordance with accepted academic practice. No use, distribu-tion or reproduction is permitted which does not comply with these terms. 


\section{LIST OF TABLE}

1 Hasil Penelitian Motivasi Belajar Selama Pembelajaran Daring Siswa SMA-Sederajat di Jawa Timur . 
TABLE1/Hasil Penelitian Motivasi Belajar Selama Pembelajaran Daring Siswa SMA-Sederajat di Jawa Timur

\section{Pertanyaan}

Prosentase

\begin{tabular}{|c|c|c|c|c|c|}
\hline $\begin{array}{l}\text { Selama masa belajar daring ini, } \\
\text { saya mengerjakan tugas sekolah } \\
\text { dengan baik }\end{array}$ & $3 \%$ & $22,2 \%$ & $1,2 \%$ & $49,5 \%$ & $10,1 \%$ \\
\hline $\begin{array}{l}\text { Selama masa belajar daring ini, } \\
\text { saya mengerjakan tugas sekolah } \\
\text { dengan tepat waktu }\end{array}$ & $2 \%$ & $21,2 \%$ & $18,2 \%$ & $46,5 \%$ & $15,2 \%$ \\
\hline $\begin{array}{l}\text { Saya mengikuti pembelajaran } \\
\text { daring dengan antusias }\end{array}$ & $9,1 \%$ & $16,2 \%$ & $28,3 \%$ & $38,4 \%$ & $11,1 \%$ \\
\hline Saya memperhatikan setiap & & & & & \\
\hline $\begin{array}{l}\text { penjelasan dari guru saat } \\
\text { pembelajaran daring } \\
\text { Saya menambah jam belajar }\end{array}$ & $5,1 \%$ & $13,1 \%$ & $23,2 \%$ & $47,5 \%$ & $13,1 \%$ \\
\hline $\begin{array}{l}\text { saya diluar pembelajaran daring } \\
\text { yang telah diberikan guru } \\
\text { Selama masa belajar daring ini, } \\
\text { saya tidak menyontek teman }\end{array}$ & $5,1 \%$ & $26,3 \%$ & $34,3 \%$ & $28,3 \%$ & $8,1 \%$ \\
\hline $\begin{array}{l}\text { atau mencari jawaban dari } \\
\text { google saat mengerjakan tugas } \\
\text { dari guru }\end{array}$ & $15,2 \%$ & $33,3 \%$ & $35,4 \%$ & $15,2 \%$ & $6,1 \%$ \\
\hline Pembelajaran daring membuat & & & & & \\
\hline $\begin{array}{l}\text { saya lebih memahami pelajaran } \\
\text { yang diberikan guru }\end{array}$ & $37,4 \%$ & $33,3 \%$ & $21,2 \%$ & $9,1 \%$ & $3 \%$ \\
\hline $\begin{array}{l}\text { Pembelajaran daring membuat } \\
\text { saya semakin semangat belajar }\end{array}$ & $26,3 \%$ & $34,3 \%$ & $22,2 \%$ & $13,1 \%$ & $5,1 \%$ \\
\hline $\begin{array}{l}\text { Pembelajaran daring tidak } \\
\text { membuat saya bosan dan stress } \\
\text { Pembelajaran daring yang }\end{array}$ & $25,3 \%$ & $37,4 \%$ & $22,2 \%$ & $11,1 \%$ & $4 \%$ \\
\hline $\begin{array}{l}\text { diberikan guru sangat mudah } \\
\text { untuk diakses }\end{array}$ & $5,1 \%$ & $23,2 \%$ & $32,3 \%$ & $37,4 \%$ & $4 \%$ \\
\hline $\begin{array}{l}\text { Saya lebih antusias belajar } \\
\text { dalam pembelajaran } \\
\text { daripada pembelajaran } \\
\text { offline }\end{array}$ & $35,4 \%$ & $38,4 \%$ & $15,2 \%$ & $8,1 \%$ & $5,1 \%$ \\
\hline $\begin{array}{l}\text { Pembelajaran daring yang } \\
\text { diberikan guru tidak menguras } \\
\text { kuota internet saya }\end{array}$ & $40,4 \%$ & $31,3 \%$ & $16,2 \%$ & $11,1 \%$ & $5,1 \%$ \\
\hline $\begin{array}{l}\text { Guru sangat maksimal dalam } \\
\text { memberikan pengajaran pada } \\
\text { saat pembelajaran daring }\end{array}$ & $13,1 \%$ & $21,2 \%$ & $25,3 \%$ & $37,4 \%$ & $8,1 \%$ \\
\hline $\begin{array}{l}\text { Pada saat pembelajaran daring } \\
\text { berlangsung, saya tidak } \\
\text { melakukan apapun (makan, } \\
\text { tidur, bermain game) kecuali } \\
\text { mengikuti pembelajaran dengan } \\
\text { baik }\end{array}$ & $7,1 \%$ & $34,3 \%$ & $36,4 \%$ & $23,2 \%$ & $4 \%$ \\
\hline $\begin{array}{l}\text { Saya berharap pembelajaran } \\
\text { daring dapat dilakukan terus } \\
\text { menerus kedepannya }\end{array}$ & $47,5 \%$ & $26,3 \%$ & $16,2 \%$ & $8,1 \%$ & $6,1 \%$ \\
\hline $\begin{array}{l}\text { Pembelajaran } \\
\text { memudahkan saya untuk } \\
\text { melakukan pembelajaran secara } \\
\text { kelompok }\end{array}$ & $26,3 \%$ & $25,3 \%$ & $21,2 \%$ & $25,3 \%$ & $5,1 \%$ \\
\hline $\begin{array}{l}\text { Saya tidak menemukan kendala } \\
\text { apapun terkait pembelajaran } \\
\text { daring yang diberikan oleh guru }\end{array}$ & $27,3 \%$ & $40,4 \%$ & $22,2 \%$ & $10,1 \%$ & $2 \%$ \\
\hline $\begin{array}{l}\text { Pada saat pembelajaran daring } \\
\text { berlangsung, diskusi online } \\
\text { berlangsung sacara kondusif } \\
\text { dan aktif }\end{array}$ & $13,1 \%$ & $2,3 \%$ & $30,3 \%$ & $28,3 \%$ & $4 \%$ \\
\hline $\begin{array}{lll}\begin{array}{l}\text { Pembalajaran } \\
\text { dilakukan }\end{array} & \begin{array}{c}\text { daring } \\
\text { oleh }\end{array} & \begin{array}{l}\text { yang } \\
\text { guru }\end{array}\end{array}$ & & & & & \\
\hline $\begin{array}{l}\text { menggunakan waktu yang relatif } \\
\text { singkat dari pembelajaran offline } \\
\text { seperti biasanya }\end{array}$ & $5,1 \%$ & $6,1 \%$ & $15,2 \%$ & $60,6 \%$ & $15,2 \%$ \\
\hline $\begin{array}{l}\text { Sejak masa pembelajaran } \\
\text { daring, pengetahuan saya lebih } \\
\text { meningkat dibanding } \\
\text { pengetahuan yang saya miliki } \\
\text { semasa pembelajaran offline }\end{array}$ & $22,2 \%$ & $31,3 \%$ & $28,3 \%$ & $19,2 \%$ & $3 \%$ \\
\hline
\end{tabular}




\section{LIST OF FIGURE}

1 Hasil Skala Penelitian Motivasi Belajar Siswa Selama Pembelajaran Daring Siswa SMA - Sederajat di Jawa Timur

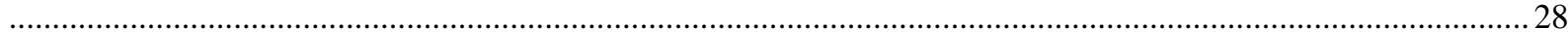

2 Diagram Penelitian Kota-kota di Jawa Timur yang Melaksanakan Pembelajaran Daring ..................................22 


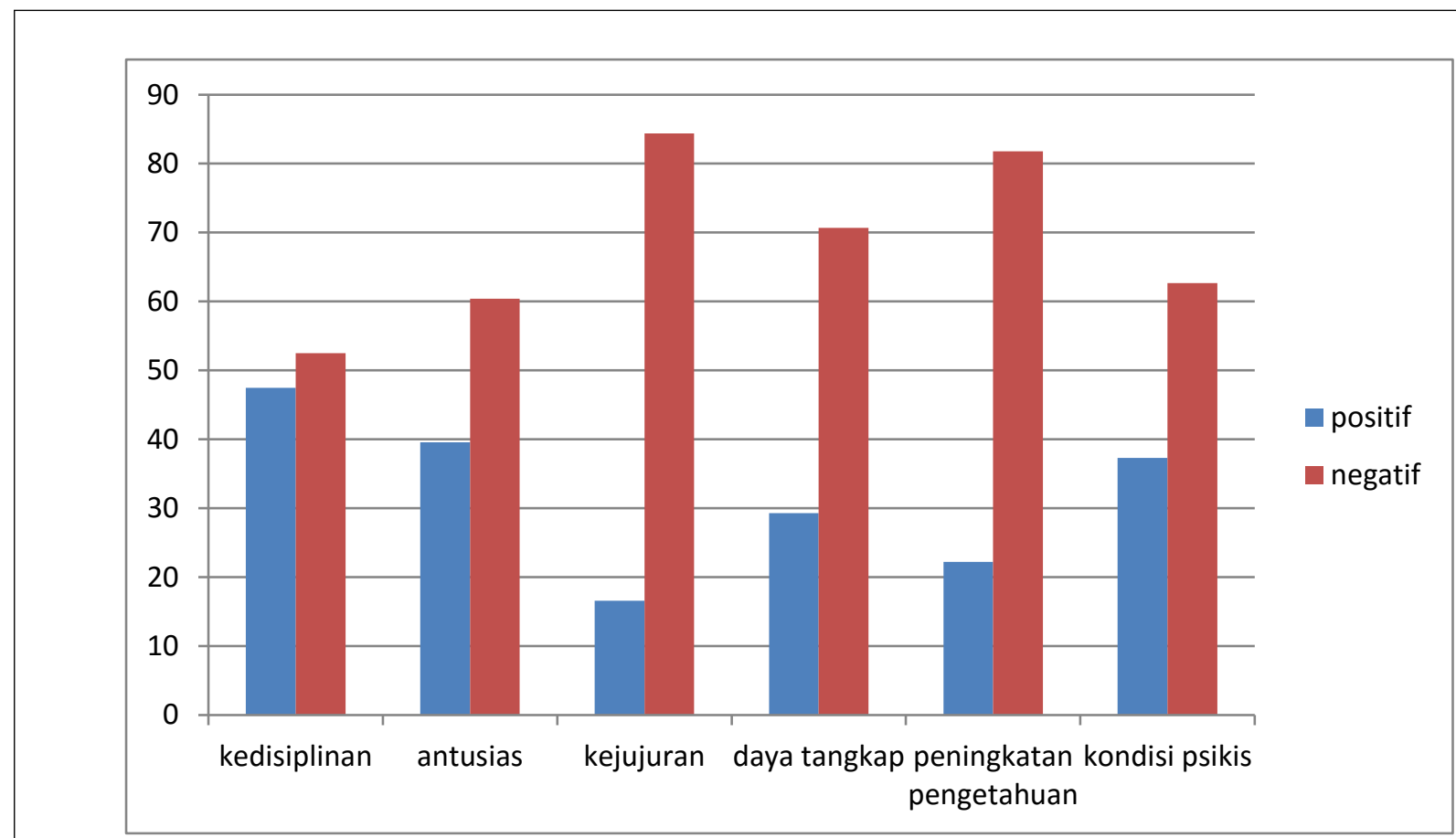

FIGURE 1 / Hasil Skala Penelitian Motivasi Belajar Siswa Selama Pembelajaran Daring Siswa SMA - Sederajat di Jawa Timur 


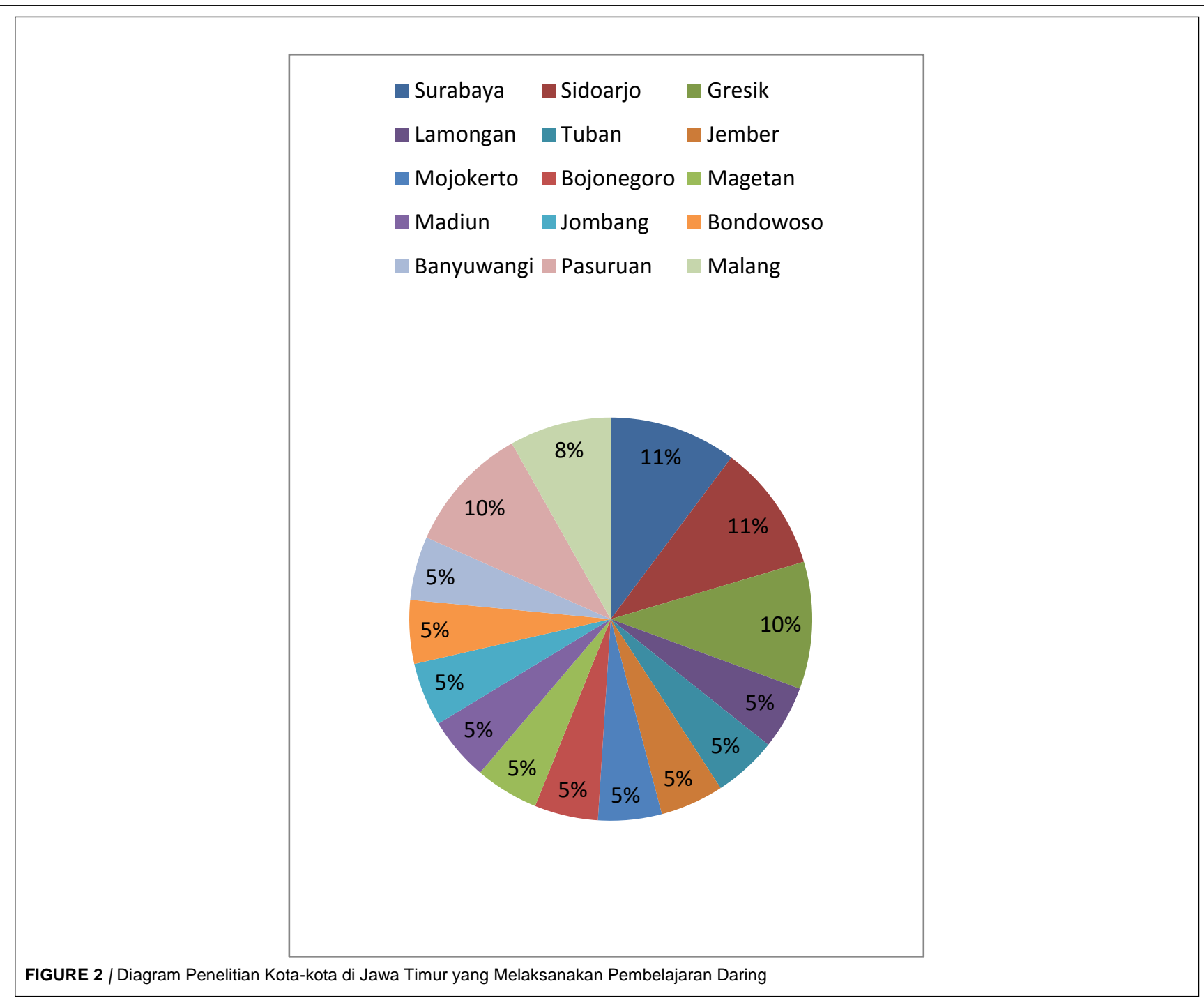

